\title{
The effect of glycerol addition as plasticizer in Spirulina platensis based bioplastic
}

\author{
Dianursanti $^{1, *}$, Misri Gozan ${ }^{1}$, and Citra Noviasari ${ }^{1}$ \\ ${ }^{1}$ Department of Chemical Engineering, Faculty of Engineering, Universitas Indonesia, Kampus UI Baru, 16424, Depok
}

\begin{abstract}
Bioplastic is one of the breakthroughs in the effort to reduce plastic waste. The bioplastic can be produced from microalgae with a high protein content, such as Spirulina platensis. The aim of this research was to produce $S$. platensis-based plastic with mechanical properties that mimics the commercial plastic bags. The microalgae were mixed with polyvinyl and maleic anhydride as compatibilizer to strengthen the bond between the microalgae and polymer. Glycerol was added as plasticizer to increase the flexibility. Observation was carried out on tensile strength and elongation of bioplastic with a variation of $15,20,25$, and $30 \mathrm{wt} \%$ of glycerol content. The results show that the optimum plasticizer composition for this $S$. platensis-based bioplastic film was $30 \mathrm{wt} \%$, which shows the tensile strength at $27.7 \mathrm{kgf} / \mathrm{cm}^{2}$ and elongation at $66 \%$. The tensile strength was very close to that of commercial plastic bags. The elongation property should be improved in order to be utilized for plastic bags. However, this bioplastic is very suitable for food, pharmacy, and cosmetic packaging materials that do not need high elongation.
\end{abstract}

\section{Introduction}

Microalgae is a promising renewable feedstock to produce biofuel, biochemistry, and high value product [1]. The main advantages of using microalgae are its characteristics such as ease of cultivation, does not take a long time for cultivation, and only need small area compared to terrestrial crops [2]. Microalgae also have the ability to reduce high amount of $\mathrm{CO}_{2}$ in the atmosphere through oxygenic photosynthesis [3-4]. Microalgae has the potential to act as filler in the production of polymer matric composite [5]. The utilization of microalgae as filler in polymer matrix composite production is fairly considerable, such as PVC-Chlorella, PLA-algae, PEChlorella, PBS-Spirulina, etc [5-8]. The purposes of using microalgae as filler are to reduce cost and reduce $\mathrm{CO}_{2}$ concentration in the atmosphere [3-5].

In the last few years, polyvinyl alcohol (PVA) attracts attention to commercial application because of its properties that have high tensile strength, biodegradable, and soluble in water so PVA is used as feedstock in composite production [1]. Utilization of PVA is ranging from food packaging, construction, electronics, etc. Based on the market research by Grand View Research, the number of PVA market in United States was estimated at 172.8 kilo tons in 2016 and it is expected to grow at a Compound Annual Growth Rate (CAGR) of 5.4\% from 2017 to 2025. The price of PVA quoted from Sigma Aldrich is approximately 4 million Indonesian Rupiah per kilogram. In attempt to reduce this PVA demand, it can be blended with biopolymer. PVA is suitable to be blended with biopolymer because of its high polarity, can be manipulated water solutions, and is also biodegradable
[9]. In this research, bioplastics were produced by blending the PVA with biopolymer.

There are three main categories of renewable biopolymer, one of which is protein [8]. Spirulina platensis has high potential to act as filler in bioplastic composite production because of its high protein content, which is around $57 \%$ [2]. Spirulina platensis is a spiral cyanobacteria, also has chlorophyll and $50-70 \%$ protein content [10]. Spirulina platensis can be cultivated in freshwater, brackish water, and sea water [10]. Due to its small cell size, protein in Spirulina platensis do not need to be extracted to be utilized so it reduces cost [8]. Therefore, in this research we do not extract the protein from microalgae. The number of microalgae used in this research was approximately 56\% and PVA used was approximately $27 \%$. The addition of microalgae until a particular composition to PVA can improve the mechanical properties of PVA [5;9]. The price of Spirulina platensis powder quoted from online marketplace is approximately 250 thousand Indonesian Rupiah per kilogram. By blending PVA with Spirulina platensis, material cost in plastic production can be reduced. The composition of Spirulina platensis below was obtained from the packaging.

Other materials needed in bioplastic production are plasticizer and compatibilizer. Plasticizer is a low molecular weight non-volatile substance used as additive to improve flexibility [11]. Because PVA is brittle, plasticizer is needed to increase the flexibility of the bioplastic film [12]. Bioplastic produced from polyethylene/Spirulina platensis/glycerol mixture has the highest tensile load with the concentration of glycerol at $11 \%$ [2]. In the concentration range between $0-50 \%$, the incorporation of glycerol did not significantly reduce film

\footnotetext{
*Corresponding author:danti@che.ui.ac.id/dianursanti@yahoo.com
} 
strength but enhanced their flexibility [11]. Compatibilizer increases the interfacial adhesion in heterogenous polymer blends resulting in better mechanical properties [13]. Dispersion between PVA and microalgae is poor so composite with $40-50 \%$ filler underwent mechanical properties decrease [9]. The use of compatibilizer can improve interfacial interaction between PVA and microalgae. Plasticizer and compatibilizer can increase mechanical properties of the bioplastic produced.

Table 1. Composition of Spirulina platensis

\begin{tabular}{|l|l|}
\hline & $(\mathrm{wt} \%)$ \\
\hline Protein & 60 \\
\hline Lipid & 6 \\
\hline Fatty Acid & $265 \mathrm{mg} / 10 \mathrm{gr}$ \\
\hline Amino Acid & $2410 \mathrm{mg} / 10 \mathrm{gr}$ \\
\hline Vitamin A & $23000 \mathrm{IU}$ \\
\hline Vitamin B1 - B3 & $2.3 \mathrm{mg} / 10 \mathrm{gr}$ \\
\hline Vitamin B6 \& B12 & $112 \mathrm{mcg}$ \\
\hline Vitamin E & $4 \mathrm{IU}$ \\
\hline Phycocianin & $20 \%$ \\
\hline Chlorophyll & $1.5 \%$ \\
\hline B-Carotenoids & $0.15 \%$ \\
\hline Pantothenic Acid & $4 \mathrm{mg} / 100 \mathrm{gr}$ \\
\hline Folic Acid & $100 \mathrm{mcg} / 100 \mathrm{~g}$ \\
\hline Polysaccharide & $0.4 \mathrm{~g} / 100 \mathrm{gr}$ \\
\hline
\end{tabular}

\section{Experimental Section}

\subsection{Materials}

Bioplastics was prepared by using PVA from PT. Brataco Co., with molecular weight $37,000 \mathrm{~g} / \mathrm{mol}$. Spirulina platensis powder was produced by Polaris, with protein content at $60 \%$. Plasticizer used was glycerol for analysis with $\geq 99.5 \%$ purity from Sigma-Aldrich. Compatibilizer used was pure maleic anhydride (MAH) for synthesis with $\geq 99 \%$ purity from Sigma-Aldrich. Pure potassium peroxodisulfate (KPS) $\geq 99 \%$ and dimethyl sulfoxide (DMSO), the initiators for compatibilizer, were bought from Sigma-Adrich. Mineral oil was used to make removing the bioplastic from the molding easier.

\subsection{Preparation of compatibilizer}

Maleic anhydride 0.15 grams, 2.5 grams polyvinyl alcohol, and $15 \mathrm{~mL}$ dimethyl sulfoxide were mixed under stirring for $120 \mathrm{~min}$, at the temperature of $100^{\circ} \mathrm{C}$, and yielded viscous suspension. Potassium peroxodisulafate was then added in the amount of 0.0125 grams and mixed under stirring for $60 \mathrm{~min}$, at the temperature of $120^{\circ} \mathrm{C}$.

\subsection{Preparation of filler}

Selected amount of glycerol was added into $15 \mathrm{~mL}$ of distilled water and stirred for $10 \mathrm{~min}$, at the temperature of $60^{\circ} \mathrm{C}$. Then, 5 grams of Spirulina platensis microalgae was added into the mixture and mixed under stirring for
$30 \mathrm{~min}$, at the temperature of $100^{\circ} \mathrm{C}$. The filler produced was in the shape of viscous suspension. The amount of glycerol was varied at $15 \mathrm{wt} \%(0.6 \mathrm{~mL}), 20 \mathrm{wt} \%(0.8 \mathrm{~mL})$, $25 \mathrm{wt} \%(1.0 \mathrm{~mL})$, and $30 \mathrm{wt} \%(1.2 \mathrm{~mL})$.

\subsection{Preparation of bioplastic film}

The compatibilizer and filler were then mixed under stirring for $20 \mathrm{~min}$, at the temperature of $120^{\circ} \mathrm{C}$. The mixture was stored for 1 day. The molding to make the bioplastic was made of glass, with $20 \mathrm{~cm} \mathrm{x} 15 \mathrm{~cm}$ dimension. Mineral oil was dabbed on the molding surface to make it easier to remove the bioplastic film produced. After 1-day storage, the mixture was stirred and heated at $120^{\circ} \mathrm{C}$ for $15 \mathrm{~min}$ before it was poured onto the molding. After that, the mixture was heated in an oven at $100^{\circ} \mathrm{C}$ for $15 \mathrm{~min}$. The bioplastic film was allowed to cool at room temperature before removed from the molding.

\subsection{Mechanical properties}

Mechanical properties of the bioplastic film that were analysed were tensile strength and elongation according to ASTM D882. Tensile strength is the maximum load where the specimen can hold its shape before failure. Elongation is the ratio between maximum length of specimen before failure and its initial strength. These characteristics usually showed in a stress-strain diagram. These properties were obtained by using Universal Tester. The sample was pulled until it was torn and these properties were measured by using extensometer. Mechanical properties of the bioplastic produced were compared with mechanical properties of traditional plastic bag.

\section{Results and Discussions}

Tensile strength and elongation of the sample were obtained at Center for Chemical and Packaging, Jakarta, and the test refers to ASTM D882. There are 4 samples in total. The sample dimension was $20 \mathrm{~cm} \times 10 \mathrm{~cm}$. The tensile strength unit was $\mathrm{kgf} / \mathrm{cm}^{2}$ and the elongation has no unit but it is shown in percentage. The results of the tests were illustrated in Figure 1 and 2.

Fig. 1 shows that in this research, the concentration of plasticizer is inversely proportional with the tensile strength of bioplastic film. The tensile strength of bioplastic film shown are $30.8 \mathrm{kgf} / \mathrm{cm}^{2}$ (15 wt $\left.\%\right), 29.6$ $\mathrm{kgf} / \mathrm{cm}^{2}$ (20 wt\%), $28.3 \mathrm{kgf} / \mathrm{cm}^{2}(25 \mathrm{wt} \%)$ and 27.7 $\mathrm{kgf} / \mathrm{cm}^{2}(30 \mathrm{wt} \%)$. A $5 \%$ increase of plasticizer content decreased the tensile strength of bioplastic film by 1.2 $\mathrm{kgf} / \mathrm{cm}^{2}$. With $10 \%$ increase of plasticizer content, the tensile strength of bioplastic film decreased by 2.5 $\mathrm{kgf} / \mathrm{cm}^{2}$. By adding the plasticizer content by $15 \%$, the tensile strength of bioplastic film decreased by 3.1 $\mathrm{kg} / \mathrm{cm}^{2}$. It can be concluded that with the addition of 1.2 $\mathrm{mL}$ glycerol, the tensile strength of bioplastic film decreased insignificantly. These decreases of tensile strength can be described by the replacement of intermolecular bond between PVA molecule with intermolecular bond between PVA and glycerol [14]. 
Therefore, the strength of the bond decreased which result in the material became easier to fail. However, the decrease of tensile strength is small because the intermolecular bond between PVA molecule and intermolecular bond between PVA and glycerol are both hydrogen bonds. The tensile strength of commercial plastic bag is $26.4 \mathrm{kgf} / \mathrm{cm}^{2}$ [15]. It can be seen that all bioplastic films have higher tensile strength. Therefore, based on its tensile strength, bioplastic film of this research can be used as commercial plastic bag.

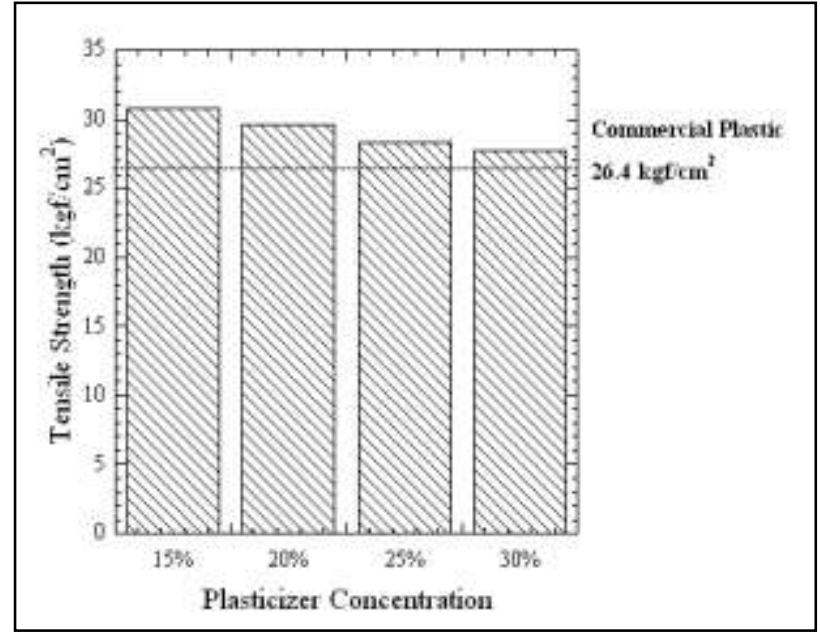

Fig 1. Tensile strength of bioplastic film with various glycerol (plasticizer) content.

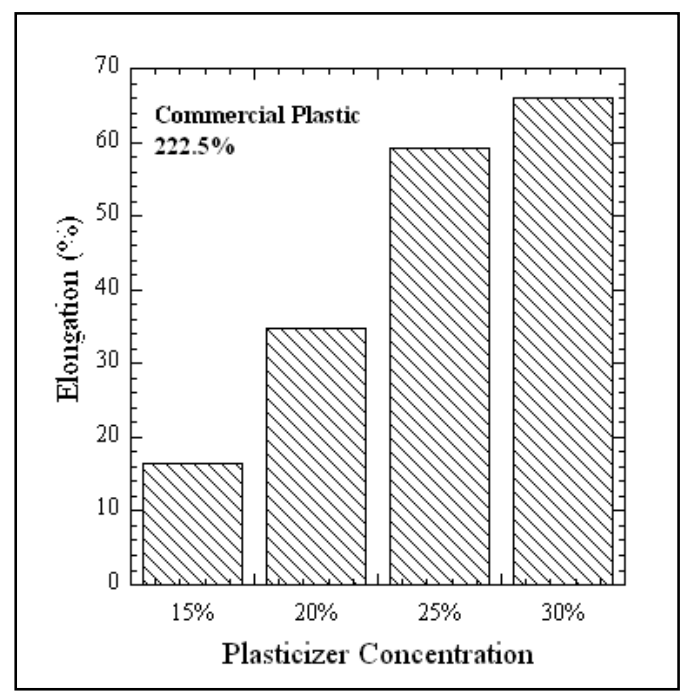

Fig 2. Elongation of bioplastic film with various glycerol (plasticizer) content.

Fig. 2 shows that in this research, the concentration of plasticizer is proportional with elongation of bioplastic film. Elongation of bioplastic films are $16.4 \%$ (15 wt $\%)$, $34.8 \%$ (20 wt $\%$ ), 59.2\% (25 wt $\%$ ), and 66\% (30 wt \%). A $5 \%$ increase of plasticizer content increased the elongation of bioplastic film by $18.4 \%$. With $10 \%$ increase of plasticizer content, the elongation of bioplastic film increased by $42.8 \%$. And $15 \%$ increase of plasticizer content increased the elongation of bioplastic film by $49.6 \%$. This shows that with the addition of $1.2 \mathrm{~mL}$ glycerol, the elongation of bioplastic film increased sharply.

As mentioned before, the intermolecular bonds between PVA molecules were replaced by intermolecular bonds between PVA and glycerol molecules. This change of intermolecular bonds caused the reduction of stiffness and increased film flexibility [14]. Therefore, the elongation of bioplastic film produced were increased as well. The elongation of commercial plastic bag is $222.5 \%$ [15]. The elongation of bioplastic film in this research were below this number. Therefore, the bioplastic film in this research cannot be used as commercial plastic bag. However, it can be used in other applications, such as packaging for food, pharmacy, and cosmetic that do not need high elongation, which is around $20 \%$ [16].

\section{Conclusion}

As mentioned, Spirulina platensis is one of the promising biopolymer materials because of its high protein content. The addition of glycerol as plasticizer in Spirulina platensis-based bioplastic resulted in an improvement of properties of the bioplastic, which is elongation. In order to get similar properties between bioplastic and commercial plastic bag, an optimum addition of glycerol is obtained at $30 \mathrm{wt} \%$. The mechanical properties of bioplastic film with $30 \mathrm{wt} \%$ glycerol obtained was 27.7 $\mathrm{kgf} / \mathrm{cm}^{2}$ tensile strength and $66 \%$ elongation. The lowest elongation was obtained from addition of $15 \mathrm{wt} \%$ glycerol, which was $15 \%$. Although bioplastic film from Spirulina platensis had higher tensile strength than commercial plastic bag, the elongation is lower. However, this bioplastic film showed promising properties to be used in other application, such as packaging for food, pharmacy, or cosmetic.

The authors gratefully thank the financial support from Universitas Indonesia through the Publikasi International Terindeks untuk Tugas Akhir Mahasiswa (PITTA) grant (No. 2416/UN2.R3.1/HKP.05.00/2018).

\section{References}

1. D.T. Tran, H.R. Lee, S. Jung, M.S. Park, J.W. Yang, and Y.K. Chang, J. Appl. Polym. Sci. 133, 525 (2016)

2. M.A. Zeller, R. Hunt, A. Jones, S. Sharma, J. Appl. Polym. Sci. 130, 3263 (2013)

3. A. Wijanarko, Dianursanti, M. Gozan, S.M.K. Andika, P. Widiastuti, H. Hermansyah, A.B. Witarto, K. Asami, R.W. Soemantojo, K. Ohtaguchi, S.S. Koo, Biotechnol. Bioprocess Eng. 11, 484 (2006)

4. A. Wijanarko, Dianursanti, A.Y. Sendjaya, H. Hermansyah, A.B. Witarto, M. Gozan, B.T. Sofyan, K. Asami, K. Ohtaguchi, R.W. Soemantojo, S.K. Song, Biotechnol. Bioprocess Eng. 13, 476 (2008).

5. M. Bulota, T. Budtova, Composites: Part A 73, 109 (2015)

6. F. Zhang, H. Kabeya, R. Kitagawa, T. Hirotsu, J. Appl. Mat. Sci. 35, 2603 (2000) 
7. T. Otsuki, F. Zhang, H. Kabeya, T. Hirotsu. J. Appl. Polym. Sci. 92, 812 (2004)

8. N. Zhu, M. Ye, D. Shi, M. Chen, Macromol. Res. 25, 165 (2017)

9. E. Chiellini, P. Cinelli, V.I. Illieva, M. Martera, Biomacromolecules 9, 1007 (2008)

10. M. Christwardana, M.M.A. Nur, Hadiyanto, J. Aplikasi Tekno. Pangan 2, 1 (2013)

11. M.G.A. Vieira, M.A. da Silva, L.O. dos Santos, M.M. Beppu, Eur. Polym. J. 47, 254 (2011)

12. Z.X. Ooi, H. Ismail, A.A. Bakar, N.A.A. Aziz, Polym. - Plastic Techno. Eng. 51, 432 (2012)

13. B. Imre, B. Pukánszky, Eur. Polym. J. 49, 1215 (2013)

14. L.M. Sanyang, S.M. Sapuan, M. Jawaid, M.R. Ishak, J. Sahari, Polymers 7, 1106 (2015)

15. K.S. Chan, H.B. Senin, I. Naimah, AIP Conference Proceedings 1136, 366 (2009)

16. W.M. Siah, A. Aminah, A. Ishak, IFRJ 22, 2230 (2015) 